\title{
RECENZJA OPRACOWANIA WOJCIECHA RADECKIEGO - USTAWA O ODPADACH. KOMENTARZ, WARSZAWA 2013
}

\section{REVIEW - WOJCIECH RADECKI, USTAWA O ODPADACH. KOMENTARZ, WARSZAWA 2013}

\section{STRESZCZENIE}

Celem opracowania jest charakterystyka i ocena publikacji naukowej: Wojciech Radecki, Ustawa o odpadach. Komentarz, Warszawa 2013

\section{Słowa kluczowe}

Odpady, gospodarka odpadami, ochrona środowiska.

* Dr nauk prawnych, radca prawny, EWSPA Warszawa. 


\section{ABSTRACT}

Objective of the review is to characterize and evaluate monograph: Wojciech Radecki, Ustawa o odpadach. Komentarz, Warszawa 2013

\section{Keywords}

Waste management, waste management, environmental protection.

Recenzowana praca stanowi pierwszy komentarz do ustawy o odpadach z dnia 14 grudnia 2012 r. Dotychczas nie pojawiła się żadna publikacja o charakterze całościowego komentarza czy monografii wspomnianego aktu prawnego. Z dużym zadowoleniem należy przyjąć opracowanie przepisów nowej ustawy o odpadach. Z pewnością to kompleksowe omówienie przepisów będzie użyteczne zarówno dla teoretyków, a przede wszystkim dla praktyków zajmujących się różnymi zagadnieniami gospodarowania odpadami. Publikacja jest niezbędna zarówno dla podmiotów gospodarujących odpadami, dla prawników zajmujących się zawodowo obsługą prawną przedsiębiorców gospodarujących odpadami, jak również dla organów administracji rządowej i samorządowej i innych instytucji stosujących przepisy ustawy o odpadach. Książka jest też użyteczna dla wszystkich, którzy starają się uzyskać naukową wiedzę o zasadach prawnych gospodarowania odpadami oraz dla tych czytelników, którzy chcą zrozumieć funkcjonowanie obecnego systemu rozwiązań prawnych w dziedzinie gospodarowania odpadami.

Autor porządkuje w sposób kompleksowy poszczególne zagadnienia związane z gospodarowaniem odpadami. Problematyka gospodarowania odpadami jest ściśle związana ze stosowaniem prawnych instytucji ochrony środowiska w praktyce. Nie bez znaczenia jest $\mathrm{w}$ tej mierze także aspekt teoretyczny, który podlega ciągłemu rozwojowi ze względu na zmieniające się i nowe regulacje w tym obszarze. Stąd też za trafne uznać należy uwagi zawarte $\mathrm{w}$ części pierwszej opracowania, odnoszące się do zagadnień wprowadzających do problematyki od- 
padów, rozwoju przepisów o odpadach i miejsca ustawy o odpadach w polskim systemie prawnym.

Recenzowana praca podzielona została na dwie części. Pierwsza dotyczy wspomnianych zagadnień wprowadzających, druga - uporządkowana została według systematyki ustawy. W drugiej części autor artykuł po artykule omawia problematykę szeroko pojętego gospodarowania odpadami. Za prawodawcą, autor omawia nowe definicje oraz wskazuje zasady dokonywania klasyfikacji odpadów i postępowania z nimi. Omawiając poszczególne przepisy autor słusznie nawiązuje też do ścisłego związku ustawy o odpadach z przepisami unijnymi. Część druga zawiera omówienie zagadnień ogólnych ustawy o odpadach, opracowanie zasad gospodarki odpadami, planów oraz uprawnień wymaganych do gospodarowania odpadami oraz prowadzenia rejestru, ewidencji i sprawozdawczości, bazy danych o produktach i opakowaniach, szczególnych zasad gospodarowania niektórymi rodzajami odpadów, wymagań dotyczących przetwarzania odpadów, zadań z zakresu administracji rządowej, przepisów karnych i administracyjnych kar pieniężnych, m.in. przepisów przejściowych i końcowych.

Książka wydana została w 2013 r. przez Wydawnictwo Wolters Kluwer i ma 528 stron. W opracowaniu uwzględniono stan prawny i literatury na dzień 1 czerwca 2013 r. Publikacja jest kontynuacją i aktualizacją komentarza do ustawy o odpadach wydawanego w latach poprzednich, stąd stanowi ona trzecie wydanie.

Podstawową metodą stosowaną przez autora jest analiza zagadnień metodą dogmatyczną uzupełnioną metodą historycznoprawną, które to metody pozwoliły na szersze spojrzenie na polski system gospodarowania odpadami. Autor akcentuje też powiązania ustawy z prawem Unii Europejskiej. Przyjęte metody badawcze pozwoliły na dokładne rozpoznanie ewolucji ustawodawstwa polskiego oraz jego charakteru w związku z założeniami prawodawcy unijnego.

Praca zawiera również treść załączników ustawy o odpadach, co ułatwia czytelnikowi posługiwanie się przepisami. Oprócz tego w publikacji zawarto indeks rzeczowy również ułatwiający sprawne znalezienie zagadnienia, którym czytelnik jest 
zainteresowany. Za szczególnie cenną należy uznać bibliografię, która zachęca do dalszych studiów nad problematyką prawnych zagadnień gospodarowania odpadami oraz ułatwia samodzielne poszukiwania w tym obszarze wiedzy.

Podsumowując, należy wskazać, że Autor skoncentrował się na węzłowych zagadnieniach omawianej tematyki. Jednocześnie przedstawione rozważania są szczegółowe, wyczerpujące i uporządkowane. Walorem książki jest jej wymiar praktyczny, pozwalający na rozstrzygnięcie wielu problemów związanych ze stosowaniem przepisów ustawy o odpadach. Z całym przekonaniem można ją rekomendować wszystkim czytelnikom zainteresowanym problematyką istotnego fragmentu problematyki prawa ochrony środowiska, jakim jest gospodarka odpadami.

Kontakt e-mail:

karolinaszuma@gmail.com 